Indian Journal of Science and Technology

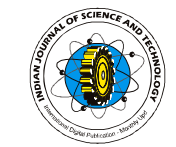

Vol.2 No. 12 (Dec. 2009)

ISSN: 0974- 6846

\title{
Application of latin square design for the evaluation and screening of supplementary nitrogen source for L-asparaginase production by Aspergillus terreus MTCC 1782
}

\author{
G. Baskar and S.Renganathan ${ }^{1}$ \\ Department of Biotechnology, St. Joseph's College of Engineering, Chennai-600 119, India. \\ ${ }^{1}$ Department of Chemical Engineering, Alagappa College of Technology, Anna University, Chennai - 600 025, India. \\ basg2004@gmail.com; rengsah@rediffmail.com
}

\begin{abstract}
The effect of ammonium chloride, urea and sodium nitrate as supplementary nitrogen source on the production of extracellular L-asparaginase using Aspergillus terreus MTCC 1782 was investigated using 5level Latin square design. The statistical reliability and significance of the variables was studied by performing ANOVA for experimental L-asparaginase activity using Dataplot software. Among the supplementary nitrogen sources studied, ammonium chloride was found to be the best for maximum L-asparaginase activity (confidence level of $96.61 \%$ ) with less biomass formation (confidence level of $21.93 \%$ ). The maximum L-asparaginase activity obtained was of $26.47 \mathrm{IU} / \mathrm{mL}$ by $A$. terreus MTCC 1782 using groundnut oil cake powder as natural substrate in submerged fermentation.
\end{abstract}

Keywords: Aspergillus terreus, L-asparaginase, latin square design.

\section{Introduction}

L-asparaginase (L-asparagine amino hydrolase, E.C.3.5.1.1) catalyzes the hydrolysis of $L$-asparagine into L-aspartic acid and ammonia. This has been a clinically acceptable anti tumor agent for the effective treatment of acute lymphoblastic leukemia and lymphosarcoma. Lasparagine is an essential amino acid for the growth of tumor cells, whereas the growth of normal cells is not dependent on its requirement as it can be synthesized in amounts sufficient for their metabolic needs using their own enzyme L-asparagine synthetase. The presence of L-asparaginase deprives the tumor cells of an important growth factor and they fail to survive (Broome, 1961; Broome, 1965; Berenbaum et al., 1970). Recombinant Lasparaginase of $A$. niger and $A$. oryzae used in processing of starchy food products. It converts the amino acid asparagine to aspartic acid then reduces acrylamide formation during processing of high starch food products (FAO/WHO, 2001; Pedreschi et al., 2008). The demand for this enzyme is expected to increase several fold in coming years due to its potential industrial application as food processing aid besides clinical applications.

L-asparaginase produced by several bacterial sources leads to adverse side effects in human trials. Therefore, there is a search for the other sour ces for Lasparaginase production with less adverse effects. It has been observed that eukaryotic microorganisms like yeast and filamentous fungi are potential sources for Lasparaginase production. These studies suggest Lasparaginase production by filamentous fungi is under nitrogen regulation (Sarquis et al., 2004). The $A$. nidulans (Shaffer et al., 1988), A. terreus (Ali et al., 1994; Sarquis et al., 2004) using synthetic substrates and $A$. niger (Mishra, 2006) using agro-wastes from three leguminous crops were reported to produce L-asparaginase which was not toxic and appeared to have myelosuppressive and immunosuppressive activity. Mesophilic fungus Cylindrocarpon obtusisporum MB-10 was also reported to produce intracellular L-asparaginase (Raha et al., 1990), which was very specific for L-asparagine and did not hydrolyse D-asparagine or L-glutamine. However, only few researchers studied the production of L-asparaginase using naturally available cheaper substrate. It also has been observed from our preliminary study that $A$. terreus MTCC 1782 was found to be a potential fungal source for $\mathrm{L}$-asparaginase and used for further investigation in this study.

Statistical experimental designs have been used in several steps of optimization strategy and it is better acknowledged than traditional one variable at a time method (Kwak et al., 2006; Zheng et al., 2008). Statistical experimental design such as Latin Square Design (LSD) minimizes the error in determining the effect of parameters, which allows simultaneous, systematic, and efficient variation of all parameters than classical method. LSD was first used in agricultural research to adjust for fertility differences in two physical directions (Box et al., 1978; Torbjorn et al., 1998).

Identifying a low cost substrate is important to develop an economically viable bioprocess for any product. Groundnut oil cake is used as animal feed, was obtained as waste after extraction oil form groundnut. In the present work the groundnut oil cake powder (particle size of $80 / 120$ mesh) was used as alternate substrate to synthetic L-proline. LSD was used to evaluate and compare the effect of urea, ammonium chloride and sodium nitrate as independent supplementary nitrogen source on production of extracellular L-asparaginase by $A$. terreus MTCC 1782 in submerged fermentation using groundnut oil cake powder as substrate.

\section{Materials and methods Fungal strain}

The filamentous fungi $A$. terreus MTCC 1782 was obtained from Institute of Microbial Technology, Chandigarh, India. The spores and mycelial fragments of this fungus was cultivated in Czapek agar slants at $37^{\circ} \mathrm{C}$ for 4 days, stored at $4^{\circ} \mathrm{C}$ and periodically subcultured.
Research article

(cIndian Society for Education and Environment (iSee)
"L-asparaginase"

http://www.indjst.org
Baskar \& Renganathan Indian J.Sci.Technol. 


\section{Ground nut oil cake powder}

The ground nut oil cake used in this work was purchased from local market (Chennai, India), dried overnight at $65^{\circ} \mathrm{C}$ to remove moisture if any, powdered and sieved. The ground nut oil cake powder passed through 80 and retained by 120 meshes was used as natural substrate for production of L-asparaginase.

Inoculum culture

Inoculum culture was cultivated in modified Czapek agar slants with the following ingredients in g. Solution-A: L-asparagine, $1.0 ; \mathrm{NaNO}_{3}, 4.0 ; \mathrm{KCl}, 1.0 ; \mathrm{MgSO}_{4} .7 \mathrm{H}_{2} \mathrm{O}$, $0.052 ; \mathrm{FeSO}_{4} .7 \mathrm{H}_{2} \mathrm{O}, 0.02$; were dissolved in $100 \mathrm{~mL}$ of distilled water and stored in refrigerator. Solution-B: $\mathrm{K}_{2} \mathrm{HPO}_{4}$ 2.0; was dissolved in $100 \mathrm{~mL}$ of distilled water and stored in refrigerator. Solution-C: $\mathrm{ZnSO}_{4} .7 \mathrm{H}_{2} \mathrm{O}$ 1.0; was dissolved in $100 \mathrm{~mL}$ of distilled water. Solution-D: 0.5 gram of $\mathrm{CuSO}_{4} . \mathrm{H}_{2} \mathrm{O}$ 0.5; was dissolved in $100 \mathrm{~mL}$ of distilled water. For one litre of modified Czapek-Dox was prepared using $50 \mathrm{~mL}$ of solution-A, $50 \mathrm{~mL}$ of solution-B, $1 \mathrm{~mL}$ of solution-C, solution-D, $30 \mathrm{~g}$ of glucose and $20 \mathrm{~g}$ of agar mixed in $900 \mathrm{~mL}$ distilled water. The inoculum culture slants were incubated at $37^{\circ} \mathrm{C}$ for 4 days. Inoculum culture as conidial suspensions was prepared with concentrations of $10^{7}$ to $10^{8}$ conidia per $\mathrm{mL}$.

\section{Production and isolation of crude enzyme}

Based on LSD experiment design, $100 \mathrm{~mL}$ of liquid Czapek-Dox media modified with different supplementary nitrogen source (Sodium nitrate, Urea and Ammonium chloride), $2 \%$ groundnut oil cake powder, $1 \%$ Lasparagine, $0.2 \%$ glucose, $0.152 \% \mathrm{~K}_{2} \mathrm{HPO}_{4}, 0.052 \% \mathrm{KCl}$, $0.052 \% \mathrm{MgSO}_{4} .7 \mathrm{H}_{2} \mathrm{O}$, traces of $\mathrm{ZnSO}_{4} .7 \mathrm{H}_{2} \mathrm{O}$ and $\mathrm{FeSO}_{4} .7 \mathrm{H}_{2} \mathrm{O}$ was prepared in $250 \mathrm{~mL}$ in Erlenmeyer flask. Erlenmeyer flask were inoculated with $1 \mathrm{~mL}$ of conidial suspension and submitted to orbital shaking at $160 \mathrm{rpm}, 30^{\circ} \mathrm{C}$ and $\mathrm{pH} 6.2$ for 4 days. Then culture suspension was filtered through whattman-2 filter paper and cell-free filtrate was used as crude enzyme solution for estimation of L-asparaginase activity.

Assay of L-asparaginase activity

L-asparaginase activity of the crude enzyme solution was determined by Nesslarization, the most commonly used method for estimation of L-asparaginase activity. The quantity of ammonia formed during the hydrolysis of $0.04 \mathrm{M}$ L-asparagine was estimated using Nessler's Reagent in spectrophotometric analysis at $480 \mathrm{~nm}$. One unit (IU) of L-asparaginase activity is defined as the amount of enzyme which liberates 1 umole of ammonia per minute under the standard assay conditions (Wriston \& Yellin, 2001).

Comparison of supplementary nitrogen sources by latin

Table 1. Experimental variables in coded and actual units

\begin{tabular}{|l|c|c|c|c|c|}
\hline \multirow{2}{*}{$\begin{array}{c}\text { Experimental variables } \\
\text { in actual unit }\end{array}$} & \multicolumn{5}{|c|}{ Coded unit (Level) } \\
\cline { 2 - 6 } & 1 & 2 & 3 & 4 & 5 \\
\hline Sodium nitrate $\left(\mathrm{X}_{1}\right)(\%, \mathrm{w} / \mathrm{v})$ & 0 & 0.3 & 0.6 & 0.9 & 1.2 \\
\hline Urea $\left(\mathrm{X}_{2}\right)(\%, \mathrm{w} / \mathrm{v})$ & 0 & 0.4 & 0.8 & 1.2 & 1.6 \\
\hline Ammonium chloride $\left(\mathrm{X}_{3}\right)(\%, \mathrm{w} / \mathrm{v})$ & 0 & 0.4 & 0.8 & 1.2 & 1.6 \\
\hline
\end{tabular}

Research article

CIndian Society for Education and Environment (iSee)

Vol.2 No. 12 (Dec. 2009)

ISSN: 0974- 6846

\section{square design}

The statistical experimental designs are used to evaluate, screen and optimize the carbon, nitrogen sources and other medium and operating conditions. In particular the LSD is used to find the best source by evaluating and comparing the effect of various carbon or nitrogen sources (Kwak et al., 2006; Zheng et al., 2008). The effect of independent variables on response follows a linear model and is given by equation 1 . The residual standard deviation reflects the effect of variables, smaller the residual standard deviation of a variable, more the

Table 2. Latin square experimental design with Lasparaginase activity and cell mass

\begin{tabular}{|c|c|c|c|c|c|}
\hline \multirow{2}{*}{$\begin{array}{l}\text { Std. } \\
\text { Run }\end{array}$} & \multicolumn{3}{|c|}{$\begin{array}{l}\text { Variables in } \\
\text { coded unit }\end{array}$} & \multirow{2}{*}{$\begin{array}{c}\mathrm{L}- \\
\text { asparaginase } \\
\text { activity } \\
(\mathrm{IU} / \mathrm{mL})\end{array}$} & \multirow{2}{*}{$\begin{array}{c}\text { Cell } \\
\text { mass } \\
(\mathrm{mg} / \mathrm{mL})\end{array}$} \\
\hline & $X_{1}$ & $X_{2}$ & $x_{3}$ & & \\
\hline 1 & 1 & 1 & 1 & 22.55 & 7.60 \\
\hline 2 & 2 & 1 & 2 & 14.82 & 29.00 \\
\hline 3 & 3 & 1 & 3 & 13.12 & 34.00 \\
\hline 4 & 4 & 1 & 4 & 12.32 & 11.11 \\
\hline 5 & 5 & 1 & 5 & 26.45 & 9.70 \\
\hline 6 & 3 & 2 & 1 & 6.51 & 9.20 \\
\hline 7 & 4 & 2 & 2 & 14.50 & 12.70 \\
\hline 8 & 5 & 2 & 3 & 15.25 & 8.90 \\
\hline 9 & 1 & 2 & 4 & 28.32 & 5.31 \\
\hline 10 & 2 & 2 & 5 & 20.05 & 9.80 \\
\hline 11 & 5 & 3 & 1 & 4.74 & 7.90 \\
\hline 12 & 1 & 3 & 2 & 11.99 & 7.40 \\
\hline 13 & 2 & 3 & 3 & 19.89 & 3.73 \\
\hline 14 & 3 & 3 & 4 & 22.39 & 12.00 \\
\hline 15 & 4 & 3 & 5 & 21.06 & 12.30 \\
\hline 16 & 2 & 4 & 1 & 15.19 & 2.85 \\
\hline 17 & 3 & 4 & 2 & 14.72 & 2.76 \\
\hline 18 & 4 & 4 & 3 & 27.83 & 14.40 \\
\hline 19 & 5 & 4 & 4 & 22.55 & 16.60 \\
\hline 20 & 1 & 4 & 5 & 35.46 & 6.65 \\
\hline 21 & 2 & 5 & 1 & 25.59 & 13.50 \\
\hline 22 & 5 & 5 & 2 & 19.30 & 3.62 \\
\hline 23 & 1 & 5 & 3 & 21.54 & 8.100 \\
\hline 24 & 2 & 5 & 4 & 24.21 & 11.50 \\
\hline 25 & 3 & 5 & 5 & 29.33 & 5.50 \\
\hline
\end{tabular}

effect on response.

$\mathrm{Y}=\mu+R X_{1}+C X_{2}+T X_{3}$

Where $Y$ denotes any observation for which, $X_{1}$ and $X_{2}$ are blocking factors and $X_{3}$ is the primary factor. $\mu$ denotes the general location parameter, $\mathrm{R}$ denotes the residual standard deviation for $\mathrm{X}_{1}, \mathrm{C}$ denotes the residual standard deviation for $\mathrm{X}_{2}$ and $\mathrm{T}$ denotes the residual standard deviation for $\mathrm{X}_{3}$ (Box et al., 1978; Torbjorn et al., 1998).

In the present investigation three supplementary nitrogen sources such as urea, sodium nitrate and Indian J.Sci.Technol. 
ammonium chloride were explored at 5-level to study their independent effect on L-asparaginase production by A. terreus MTCC 1782. Groundnut oil cake powder was used as substrate in shake culture fermentation. Table 1 gives the coded and actual values of the variables. 5-level LSD for three variables was developed using Data plot software (Standard Engineering Division, NIST, Gaithersburg, MD 20899-8980) is given in Table 2. Experiments were conducted for L-asparaginase production by $A$. terreus MTCC 1782 as mentioned in production and isolation step. The analysis of variance (ANOVA) is applied to find the significance of the factors by providing estimates of grand mean and factor effects.

Table 3. ANOVA on LSD for L-asparaginase activity

\begin{tabular}{|c|c|c|c|c|c|}
\hline Factor & \begin{tabular}{|l|} 
Degree \\
of \\
freedom \\
(DF)
\end{tabular} & $\begin{array}{c}\text { Sum of } \\
\text { squares } \\
\text { (SS) }\end{array}$ & $\begin{array}{l}\text { Mean } \\
\text { square } \\
\text { (MS) }\end{array}$ & $\begin{array}{c}\mathrm{F}- \\
\text { value }\end{array}$ & $\begin{array}{c}\text { Confidence } \\
\text { level (\%) }\end{array}$ \\
\hline $\begin{array}{l}\text { Sodium } \\
\text { nitrate }\end{array}$ & 4 & 148.108 & 37.027 & 1.162 & 62.46 \\
\hline Urea & 4 & 274.921 & 68.730 & 2.156 & 86.38 \\
\hline $\begin{array}{l}\text { Ammonium } \\
\text { chloride }\end{array}$ & 4 & 475.985 & 118.996 & 3.733 & 96.61 \\
\hline Residual & 12 & 382.532 & 31.877 & & \\
\hline Total & 24 & 1281.546 & 53.397 & & \\
\hline \multicolumn{6}{|c|}{ Table 4. ANOVA on LSD for cell mass } \\
\hline Factor & $\begin{array}{l}\text { Degree } \\
\text { of } \\
\text { freedom } \\
\text { (DF) }\end{array}$ & $\begin{array}{l}\text { Sum of } \\
\text { squares } \\
\text { (SS) }\end{array}$ & $\begin{array}{c}\text { Mean } \\
\text { square } \\
\text { (MS) }\end{array}$ & $\begin{array}{c}\mathrm{F}- \\
\text { value }\end{array}$ & $\begin{array}{c}\text { Confidence } \\
\text { level } \\
(\%)\end{array}$ \\
\hline $\begin{array}{l}\text { Sodium } \\
\text { nitrate }\end{array}$ & 4 & 121.342 & 30.335 & 0.525 & 28.04 \\
\hline Urea & 4 & 365.985 & 91.496 & 1.583 & 75.84 \\
\hline $\begin{array}{l}\text { Ammonium } \\
\text { chloride }\end{array}$ & 4 & 100.633 & 25.158 & 0.435 & 21.93 \\
\hline Residual & 12 & 693.409 & 57.784 & & \\
\hline Total & 24 & 1281.371 & 53.390 & & \\
\hline
\end{tabular}

Results and discussion

The experimental L-asparaginase activity and cell mass were analyzed to study and evaluate the independent effect of urea, ammonium chloride and sodium nitrate as supplementary nitrogen source on L-asparaginase synthesis by $A$. terreus MTCC 1782 using groundnut oil cake powder using Data plot Software. ANOVA (a formal F-test) in Table 3 gives the F-value and confidence level of independent variables. Higher the F-value higher will be the confidence level (Zheng et al., 2008). It was observed that ammonium chloride has higher influence (confidence level of $96.61 \%$ ) on L-asparaginase production than urea (confidence level of $86.38 \%$ ) and

Research article

CIndian Society for Education and Environment (iSee)

sodium nitrate (confidence level of $62.46 \%$ ). ANOVA in Table 4 shows that ammonium chloride has lesser influence (confidence level of $21.93 \%$ ) on growth of $A$. terreus than urea (confidence level of $75.84 \%$ ) and sodium nitrate (confidence level of $28.04 \%$ ). Ammonium chloride was found to be the best supplementary nitrogen source for L-asparaginse production with less cell mass formation.

The mean, effect and residual standard deviation for L-asparaginase production and cell mass formation in Table 5 and 6 gives the independent effect of supplementary nitrogen sources at different concentration. Urea and ammonium chloride have lesser effect on L-asparaginase production at their low to middle level (concentration) and increases the Lasparaginase production $(23.99$ and $26.47 \mathrm{IU} / \mathrm{mL}$ respectively) at their higher level. Sodium nitrate has lesser effect $(17.66 \mathrm{IU} / \mathrm{mL})$ at its higher level, higher effect $(23.97 \mathrm{IU} / \mathrm{mL})$ at its lower level. The mean Lasparaginase activity of 23.97 and $23.15 \mathrm{IU} / \mathrm{mL}$ were obtained for modified Czapek-Dox media supplemented with urea and sodium nitrate respectively was comparatively low when ammonium chloride was used at high level. Urea has high influence $(18.28 \mathrm{mg} / \mathrm{mL})$ on growth at its low level (effect $>0)$ and the least effect (minimum of $8.44 \mathrm{mg} / \mathrm{mL}$ ) at its middle and higher level (effect $<0$ ) with low and constant standard deviation among the variables and their levels. Ammonium chloride and sodium nitrate have the least influence on cell mass formation (8.21 and 7.01 $\mathrm{mg} / \mathrm{mL}$ respectively) at their low level and higher level and they give higher growth at their middle level (13.83 and $12.69 \mathrm{mg} / \mathrm{mL}$ respectively). Among the supplementary nitrogen sources studied at different concentrations, modified Czapek-Dox media with groundnut oil cake and supplemented with ammonium chloride gives maximum L-asparaginase production $(26.47 \mathrm{IU} / \mathrm{mL})$ with less cell mass formation (8.79 $\mathrm{mg} / \mathrm{mL}$ ).

Table 5. Effect of supplementary nitrogen source on L-asparaginase activity

\begin{tabular}{|c|c|c|c|c|}
\hline Factor & Level & Mean & Effect & $\begin{array}{c}\text { SD } \\
\text { (Effect) }\end{array}$ \\
\hline \multirow{5}{*}{$\begin{array}{l}\text { Sodium } \\
\text { nitrate }\end{array}$} & 1 & 23.97 & 4.385 & 2.258 \\
\hline & 2 & 18.83 & -0.755 & 2.258 \\
\hline & 3 & 17.21 & -2.376 & 2.258 \\
\hline & 4 & 20.26 & 0.674 & 2.258 \\
\hline & 5 & 17.66 & -1.927 & 2.258 \\
\hline \multirow{5}{*}{ Urea } & 1 & 17.85 & -1.736 & 2.258 \\
\hline & 2 & 16.92 & -2.664 & 2.258 \\
\hline & 3 & 16.02 & -3.571 & 2.258 \\
\hline & 4 & 23.15 & 3.564 & 2.258 \\
\hline & 5 & 23.99 & 4.406 & 2.258 \\
\hline \multirow{5}{*}{$\begin{array}{l}\text { Ammonium } \\
\text { chloride }\end{array}$} & 1 & 14.92 & -4.669 & 2.258 \\
\hline & 2 & 15.06 & -4.519 & 2.258 \\
\hline & 3 & 19.53 & -0.062 & 2.258 \\
\hline & 4 & 21.95 & 2.369 & 2.258 \\
\hline & 5 & 26.47 & 6.881 & 2.258 \\
\hline
\end{tabular}

The linear model represents the effect of independent variables on Lasparaginase activity and cell mass were given in equation 2 and 3, and the Residual Standard Deviation (RSD) of model parameters were given in Table 7. Lesser the RSD higher will be the significance of the variable for maximization problem (Box et al., 1978) and vice versa for minimization.

$$
\mathrm{Y}_{\text {activity }}=7.307+6.346 X_{3}
$$

$\mathrm{Y}_{\text {biomass }}=7.306+7.683 X_{3}$

The RSD of ammonium chloride $\left(X_{3}\right)$ was low (6.346)

Baskar \& Renganathan Indian J.Sci.Technol. 
for L-asparaginase production and high (7.683) for cell mass formation. Ammonium chloride was validated as the best supplementary nitrogen source for maximum L-asparaginase production with less cell mass formation by $A$. terreus MTCC 1782 using Czapek-Dox media modified by groundnut oil cake as substrate.

The Dex-Mean plot is a Graphical ANOVA, used to evaluate the effect of independent variables on response. Fig. 1 and 2 shows the effect of supplementary nitrogen sources (Sodium nitrate - $\mathrm{X}_{1}$, Urea - $\mathrm{X}_{2}$, Ammonium chloride $-X_{3}$ ) on Lasparaginase production and

Table 7. RSD of model parameters for L-asparaginase activity and cell mass

\begin{tabular}{|l|c|c|}
\hline \multirow{2}{*}{ Model Parameter } & \multicolumn{2}{|c|}{$\begin{array}{c}\text { Residual standard deviation } \\
\text { (RSD) }\end{array}$} \\
\cline { 2 - 3 } & $\begin{array}{c}\text { L-asparaginase } \\
\text { activity }\end{array}$ & $\begin{array}{c}\text { Cell mass } \\
\text { formation }\end{array}$ \\
\hline Constant $(\mu)$ & 7.307 & 7.306 \\
\hline Sodium nitrate $\left(\mathrm{X}_{1}\right)$ & 7.528 & 7.615 \\
\hline Urea $\left(\mathrm{X}_{2}\right)$ & 7.094 & 6.765 \\
\hline Ammonium chloride $\left(\mathrm{X}_{3}\right)$ & 6.346 & 7.683 \\
\hline Constant and all factors & 5.646 & 7.602 \\
\hline
\end{tabular}

cell mass formation. Ammonium chloride was found to be primary supplementary nitrogen source for maximum Lasparaginase production (Fig.1) with low cell mass formation (Fig.2) by $A$. terreus MTCC 1782 using CzapekDox media modified with groundnut oil cake powder. The residual was plotted against normal distribution and forms an approximate linear line for both Lasparaginase production (Fig.3) and cell mass formation (Fig. 4), which indicates that the model was well fitted with the experimental results. As the residuals from the fitted model are normally distributed, all the major assumptions of the model have been validated.

\section{Conclusion}

LSD was successfully applied to find the best supplementary nitrogen source for L-asparaginase production by $A$. terreus MTCC 1782 using groundnut oil cake power as low-cost substrate. It was found that LSD is an effective statistical tool to evaluate and compare the various carbon or nitrogen sources and find the best for maximum Lasparaginase production. Among the supplementary nitrogen sources studied, ammonium chloride was found to be the best for
Vol.2 No. 12 (Dec. 2009)

ISSN: 0974- 6846

the production of L-asparaginase by $A$. terreus MTCC 1782 using a a low-cost substrate groundnut oil cake.

\section{References}

1. Ali SS, Rai V, Soni K, Kulshrestha $\mathrm{P}$ and Lai SK (1994) A fungal Lasparaginase with potential antitumor activity. Ind. J. Microbiol. 34, 73-76.

2. Berenbaum MC, Ginsburg H and Gilbert DM (1970) Effects of L-asparaginase on lymphocyte target cell reactions In vitro. Nature. 227, 1147-1148.

3. Box GEP, Hunder WG and Hunder SJ (1978) Statistics
Wiley \& Sons Inc., New York.

for experiments, John Wiley \& Sons Inc., New York.
4. Broome JD (1961) Evidence that the L-asparaginase activity of Guinea pig serum is responsible for its antilymphoma effects. Nature. 171, 1114-1115.

5. Broome JD (1965) Antilymphoma activity of Lasparaginase in vivo: Clearance rates of enzyme preparations from Guinea pig serum and yeast in relation to their effect on tumor growth. J. Natl. Cancer Inst. 35, 967-974.

6. Joint FAO/WHO Expert Committee on Food Additives (JECFA) Compendium of Food Additive Specifications (2001) General specifications and considerations for enzyme preparations used in food processing, FAO Food \& Nutrition. 52(9), 37-39.

7. Kwak KO, Jung SJ, Chumg SY, Kang CM, Huh YI and Bae S O (2006) Optimization of culture conditions for $\mathrm{CO}_{2}$ fixation by chemoautotrophic

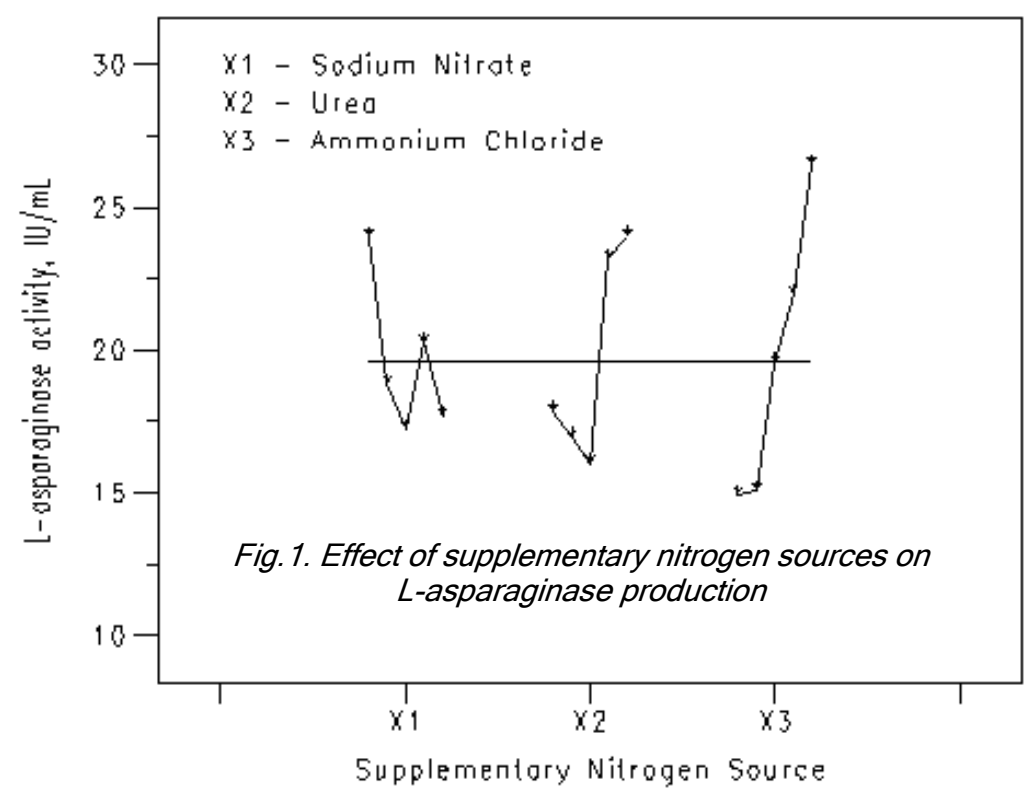


microorganism strain $\mathrm{YN}-1$ using factorial design. Biochem. Eng. J. 31, 1-7.

8. Mishra A (2006) Production of L-asparaginase, an anticancer agent, from Aspergillus niger using agricultural waste in solid state fermentation. Appl. Biochem. Biotechnol. 135, 33-42.

9. Pedreschi F, Kaack K and Granby K (2008) The effect of Asparaginase on acrylamide formation in

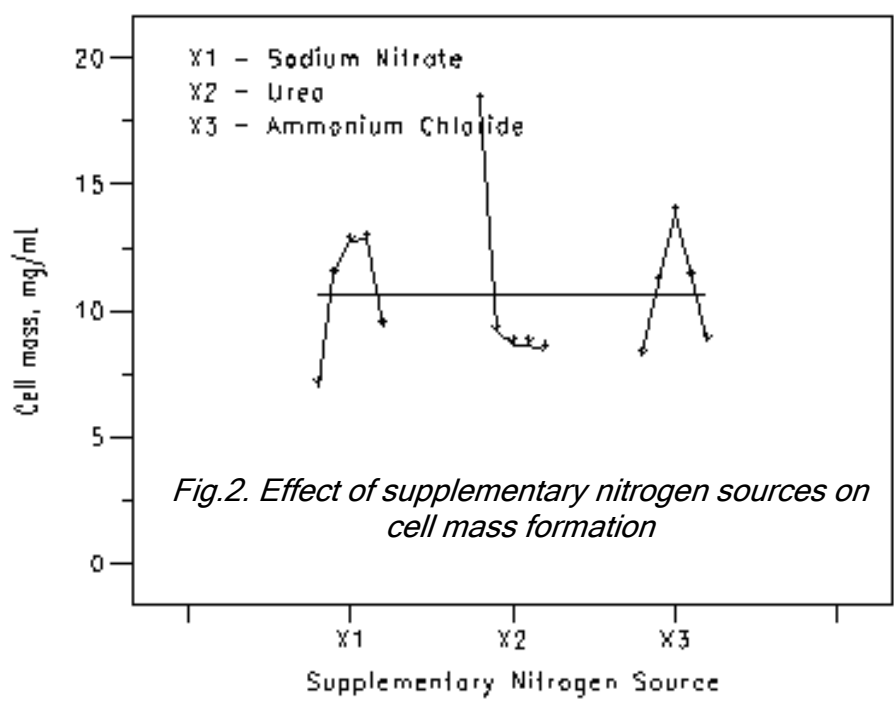

French fries. Food Chem. 109, 386-392.

10. Raha SK, Roy SK, Dey SK and Chakrabarty SL (1990) Purification and properties of an Lasparaginase from Cylindrocarpon obtusisporum MB10. Biochem. Int. 2, 987-1000.

11. Sarquis MIM, Oliviera EMM, Santos AS and DaCosta GL (2004) Production of L-asparaginase by filamentous Fungi. Mem. Inst. Oswaldo. Cruz. 99, 489-492.

12. Shaffer PM, Arst HN Jr, Estberg L, Fernando L, Tran Ly and Sitter M (1988) An asparaginase of

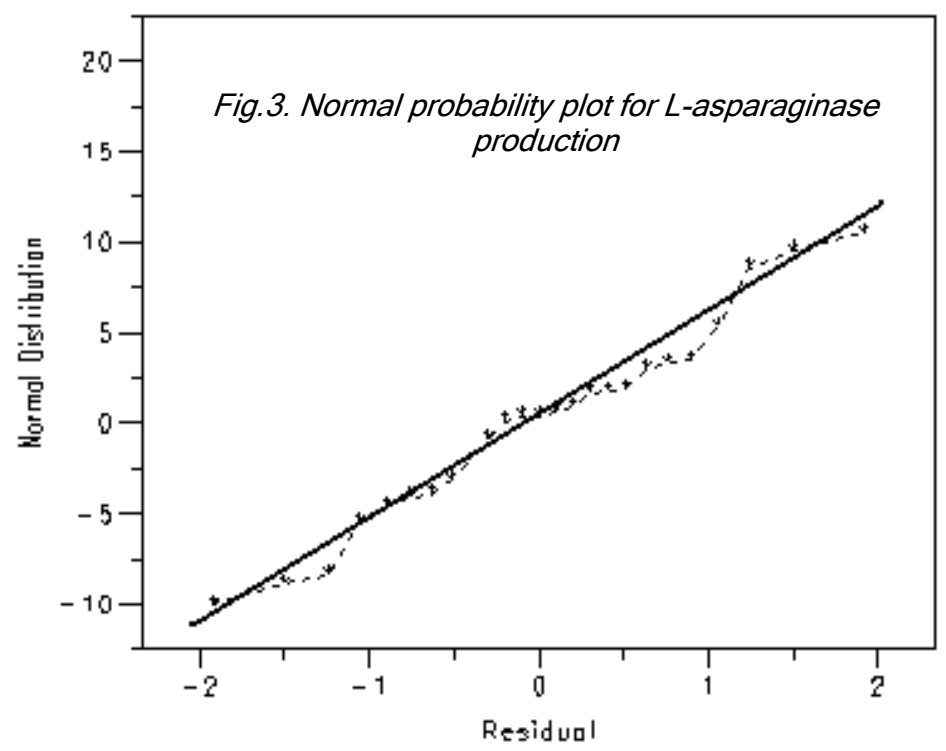

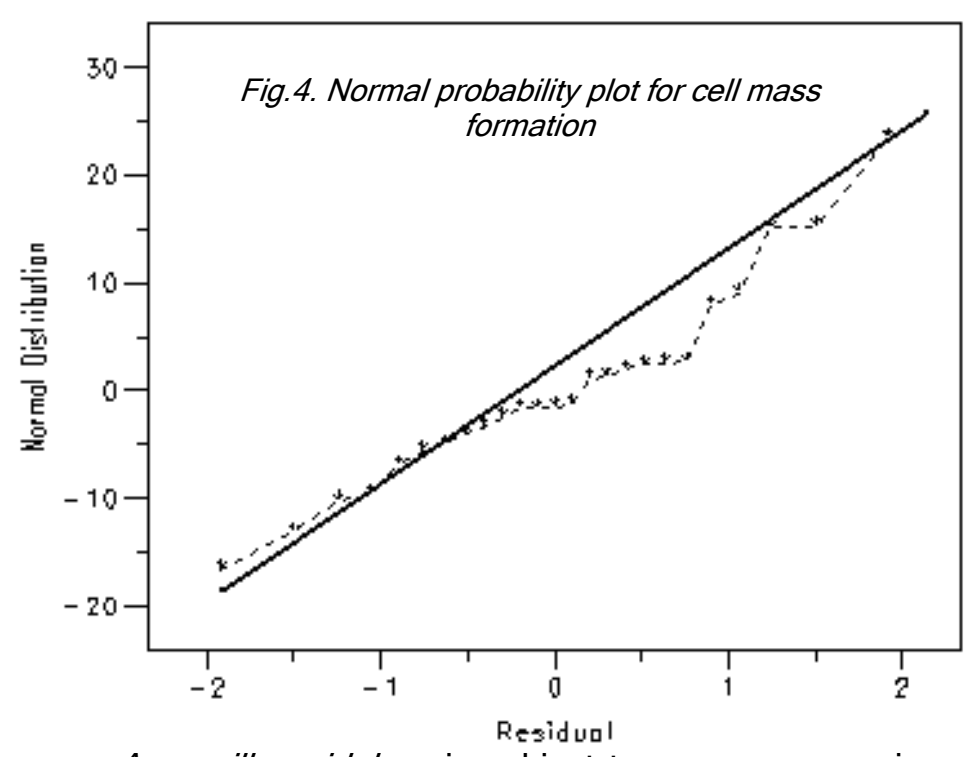

Aspergillus nidulans is subject to oxygen repression in addition to nitrogen metabolite repression. Mol. Gen. Genet. 212, 337-341.

13. Torbjorn L, Elisabeth S, Lisbeth A, Bernt T, Asa N, Jarle P and Rolf B (1998) Experimental design and optimization. Chemometr. Intell. Lab. 42, 3-40.

14. Wriston JC Jr and Yellin TO (2001) L-asparaginase a review. Adv. Enz. 39, 185-248.

15. Zheng ZM, Hu QL, Hao J, Xu F, Guo NN, Sun $Y$ and Liu DH (2008) Statistical optimization of culture conditions for 1,3-propanediol by Klebsiella pneumoniae AC 15 via Central Composite Design. Bioresour. Technol. 99, 1052-1056.
Research article

CIndian Society for Education and Environment (iSee)
Baskar \& Renganathan Indian J.Sci.Technol. 